\title{
Research
}

\section{Integrating Social Awareness Through Reading and Writing: A Classroom Action Research}

\author{
Virak Chan \\ Royal University of Phnom Penh, Cambodia
}

\begin{abstract}
As part of professional and course development, a 16-week action research project was carried out in one academic writing class at a university in Phnom Penh, Cambodia. Twenty-four students participated in this research. Students were initially introduced to a structure of a summary-response genre, and were encouraged to read a local newspaper, The Cambodia Daily, every weekday. Each week, students were required to submit one journal entry, in which they summarized one piece of news of their interest and responded to it. At the end of the 16 weeks, analysis of the contents of students' writing showed increase in their social awareness reflected in the sources of news they read and improvement in their ability to give critical responses to news they read. Implications for the use of journal and genre approach are discussed at the end of this paper.
\end{abstract}

The English Department of the University of Foreign Languages (a pseudonym referred to hereafter as ED-UFL) in Phnom Penh, Cambodia offers 4-year bachelor's degree programs in teaching English as a foreign language, English for translation and interpreting, and English for professional communication. These programs require eight semesters to complete. To enter the programs, students are required to successfully complete high school and pass the entrance examination, which puts their English proficiency at an intermediate level. They start their first year with foundation classes both in English and Khmer. For their second and third years, they take four classes all in English: Core English, Literature, Global Studies, and Writing Skills (with Research Methodology classes added to the second semester of their third year). In Year 4, their subjects vary depending on their major.

This action research project arises from issues identified in one of the writing classes at the EDUFL. The concern that students' lack of reading hinders their writing proficiency and their ability to think critically on issues surrounding them is also shared in monthly meetings at the department. 


\section{Reading-Writing Relationship}

\section{Literature Review}

Fitzgerald and Shanahan (2000) discussed reasons for the segregation between reading and writing in American education. However, they pointed out the important shared knowledge that both readers and writers used, including metaknowledge, domain knowledge about substance and content, knowledge about universal text attributes, and procedural knowledge and skill to negotiate reading and writing. They suggested that educators should consider the critical shared thinking underlying both reading and writing rather than focusing on these skills separately. Consequently, analyzing the thought processes involved in reading a text may be beneficial for understanding how the text is constructed.

In L2 (second language) writing development, reading either in L1 (first language) or L2 has played an increasingly important role. Grabe (2003) recognized this importance, especially with the increasing need to prepare students to deal with academic tasks, which usually combine reading and writing. Tabatabaei and Ali (2012) examined the effects of different types of reading tasks on the writing performance of pre- and post-intermediate EFL learners in a university in Iran. Although the study did not employ an experimental design, the pre- and post-test results showed statistically significant improvement in students' writing performance. This seemed to suggest the effectiveness of using different reading tasks (comparison / contrast, description, cause / effect, and problem / solution) to improve writing performance.

\section{Genre Approach to Writing Instruction}

Genre is a social and cognitive concept that helps group texts according to their shared linguistic and discourse features. According to Hyland, "members of a community usually have little difficulty in recognizing similarities in the texts they use frequently and are able to draw on their repeated experiences with such texts to read, understand and perhaps write them relatively easily" (2008, p. 544). For instance, readers may know immediately if a text is a manual, a love letter, or a newspaper article because of its linguistic and discourse features. Myskow and Gordon (2010) illustrated how a university application letter genre was taught in an EFL (English as a foreign language) high school writing course. Parts of the teaching included getting students to build contextual knowledge of the genre, such as the possible audience and purpose of the letter, and to analyze for the linguistic and organizational features of the model letters, which they identified as following these rhetorical moves: introduction, dreams / goals, experiences, academic accomplishments, reasons for applying, contributions, and conclusion.

Hyland (2008) believed that this approach is suitable for academic writing classes in many contexts because it illuminates how language use is constrained by social contexts. The benefits of this approach to teaching writing have also been confirmed by a number of studies (see Johns, 2003; Yasuda, 2011).

\section{Journal Writing}

Dialogue and reflective journals provide spaces for students to reflect on their learning and thinking processes and to communicate these reflections with their instructors. As Ferris (2003, p. 126) has stated, "student journal entries are typically designed to build students' fluency and reflective thinking abilities and are almost never revised by students; feedback or correction on these is not likely to have much effect on student writing."

To promote students' writing and literacy skills, many ESL (English as a second language) teachers have made quite effective use of journal writing in their classrooms. Kim (2005) used 
dialogue journal writing in his adult ESL class to promote a sense of community and engage adult ESL learners in authentic and meaningful learning. Holmes and Moulton (1997), in their multiple case studies on students' perceptions of the use of dialogue journals, reported students' positive reactions to the use of dialogue journals as a learning strategy and on the students' improved fluency and motivation in writing, which they attributed to the use of dialogue journals. Dialogue and reflective journals have also been used as an effective data collection technique in classroom research, such as in Harris (2008) and Fazio (2001).

\section{Voice in Written Text}

Voice is an important concept in reading and writing pedagogy. Elbow (2007) discussed two conflicting perspectives on this concept. On the one hand, it is seen as an important dimension of text and deserves more attention because the writer's self and rhetorical power are represented by his / her voice in the text. On the other hand, it is considered to be a misleading metaphor and does not deserve much focus since the voice that is believed to be one's own is actually greatly influenced by one's history and culture. Elbow also distinguished between text and voice:

"text" stands for words on page and "voice" for the spoken medium of language. Thus, the text lens highlights the visual and spatial features of language as print ... ; the voice lens highlights language as sounded, heard, and existing in time. The text lens foregrounds language as an abstract system (Saussure's langue) in which words have the same meaning whoever utters them in whatever context words as interchangeable and not attached to persons; the voice lens highlights how language issues from individual persons and physical bodies and how the same words differ, depending on who says them and how. (2007, p. 175)

He subsequently pointed out the common ground of these two conflicting perspectives, concluding that students need to be more empowered in the classroom. In an effort to promote student empowerment, Lovejoy (2009) encouraged students' voice through self-directed writing in his writing class; he created opportunities for students to write on topics of their interest using their own natural voice in different genres. Students' testimonials showed their positive attitudes and confidence as writers through discovery of their own voices. Drawing from Elbow's two important aspects of written discourse, text and voice, Luce-Kapler, Catlin, Sumara, and Kocher (2011) also illustrated how different writing practices can be designed to raise students' awareness in writing.

\section{Research Questions}

This action research hypothesized that utilizing the local newspaper ( The Cambodia Daily) in the classroom, training students in a summary-response genre, and providing them with opportunities to voice themselves through a dialogue journal could encourage students to expand their knowledge of their society and write more critically about it. This research was guided by the following questions:

RQ 1: Do the utilization of a local newspaper, the training of students in a summary-response genre, and journal writing in a writing class expand students' knowledge of their society? 
RQ 2: Do the utilization of a local newspaper, the training of students in a summary-response genre, and creating opportunities for them to express their voices through journal writing in a writing class increase their critical ability in writing as reflected in their responses to news in their journal entries?

\section{Methodology}

This study employs action research design, which according to Nunan (1992) is becoming popular in language education. It is usually carried out by practitioners (language teachers), and its aim is to understand or solve a specific problem. This action research identified the lack of student social awareness and critical thinking as a concern shared among instructors at the ED-UFL. Although English is a foreign language in Cambodia, it is used as a medium of instruction in almost every course at the ED-UFL. This study was guided by Koshy's (2005, p. 38) framework for action research, which includes the following steps:

- Identifying a topic and setting the context

- Reviewing and analyzing the literature

- Focusing on a topic and formulating a research question or hypothesis

- Planning activities

- Implementing and acting

- Gathering and analyzing data

- Analyzing the data further

- Reflecting on outcomes and generating evidence

- Reporting findings

This action research project was conducted in the September-to-December semester in 2012 in a writing class at the ED-UFL with 24 Cambodian students in their late teens and early twenties. This was a 16-week long semester, and classes met for 90 minutes every Tuesday and Thursday afternoon. After the introduction to their writing class in the first meeting, the students were trained in identifying voices in text and the organizational and linguistic features of a summaryresponse genre in the second and third class meetings.

\section{A Summary-Response Genre}

This genre consists of elements of both summaries and responses, which are important for writing at college and university levels. Summaries require comprehension of the reading material and a concise explanation of its main ideas. Responses involve expression of opinion, analysis, and expansion of ideas. A good example of a summary-response genre would be a letter to the editor or an opinion page in a newspaper, in which the authors summarize articles in the previous issues and respond to them. The summary-response genre was selected as part of the intervention in this action research because of its importance in academic essay examinations and papers (Meyers, 2005) and its real-life application.

\section{Two Intervening Lessons}

In the first lesson, students were given a copy of a local newspaper article from The Cambodia Daily to read. While reading, they were required to underline all the direct and indirect speech examples in the article. After reading, they worked in small groups to compare their underlined parts and to discuss whose voices were represented there (some of the voices included those of the government, NGOs (nongovernmental organizations), social groups, an individual, or the author). The teacher led class discussion asking guided questions such as: "Whose voices are represented in the article?" "Considering the issue reported in the article, is there any voice that has not been represented in it?" and "Is the report biased? And why?" This lesson draws from 
the concept of voice in Elbow (2007), Lovejoy (2009), and Luce-Kapler et al. (2011), but students did not begin to use their voice until they had analyzed the newspaper text first to see how the author represented different voices in it. To conclude the first lesson, the teacher introduced students to the summary-response genre by drawing their attention to the opinion page of The Cambodia Daily and briefly explaining that people can write a letter to the editor expressing themselves on issues they read in the paper and may even have it published on this page.

In the second lesson, the teacher gave students a copy of a letter to the editor from the opinion page of The Cambodia Daily. After the article was read, the teacher told the students that this was a typical summary-response text and got them to identify which part was a summary and which a response. This lesson is based on the genre approach to writing informed by Hyland (2008), Johns (2003), Myskow and Gordon (2010), and Yasuda (2011). In small groups, students discussed what characterizes a summary and a response in terms of purpose, organization, and word and grammatical choices. On the whiteboard, the teacher drew two separate columns, Summary and Response, and invited each group to fill in each column. The teacher asked eliciting questions such as "What is the author summarizing?" "What are some words or phrases used to make reference in the text?" "Is there any reporting verb?" "What is the purpose of the response?" How does the author organize his / her response?" and "What are some words or phrases used to express opinion?" At the end of the second lesson, the teacher reminded students about journal writing and encouraged them to read news articles and write a summary-response text for their entries.

\section{Data Collection and Analysis}

To keep track of their reading and writing, students wrote one journal entry every week on topics of their choice; these were submitted every two weeks. They were encouraged to read The Cambodia Daily, which they could borrow to read at home, and to use the summaryresponse genre for their journal entries. They were required to submit a total of 12 entries starting from Week 3, and these entries were used as data to look at the development of their reading and writing.

Data for this project were analyzed using NVivo software, which is known for its power in organizing and managing qualitative data. For anonymity purposes, all students were identified as $F$ (female) 1, F2, etc., or as $M$ (male) 1, M2, etc., in the data. Only their Journal Entries 3 to 9 were selected for analysis because at the beginning and towards the end of the semester more administrative work, such as registration, orientation, course evaluation, tests, and semester exam preparation, was performed. Thus, Entries 3 to 9 better reflected students' work. All journal entries were organized and coded using NVivo 10, and three important codes were examined: the sources of information, the issues discussed, and the level of elaboration in the summary-response genre.

\section{Research Question 1}

\section{Results}

An analysis was conducted of the sources of news the students read and responded to and the issues they discussed in their responses. Although The Cambodia Daily is a recommended source, students referred to many other Internet and broadcast sources, including Dem Ampil News (DAP), Cambodia Express News, Yahoo, CNN, the Associated Press, Channel News Asia, and the BBC. Students read the news articles both in Khmer and in English. Students' expanding knowledge of society is probably best expressed in their expanding sources of 
information as they progressed from Journal Entry 3 to 9, and this is illustrated in the model in Figure 1.

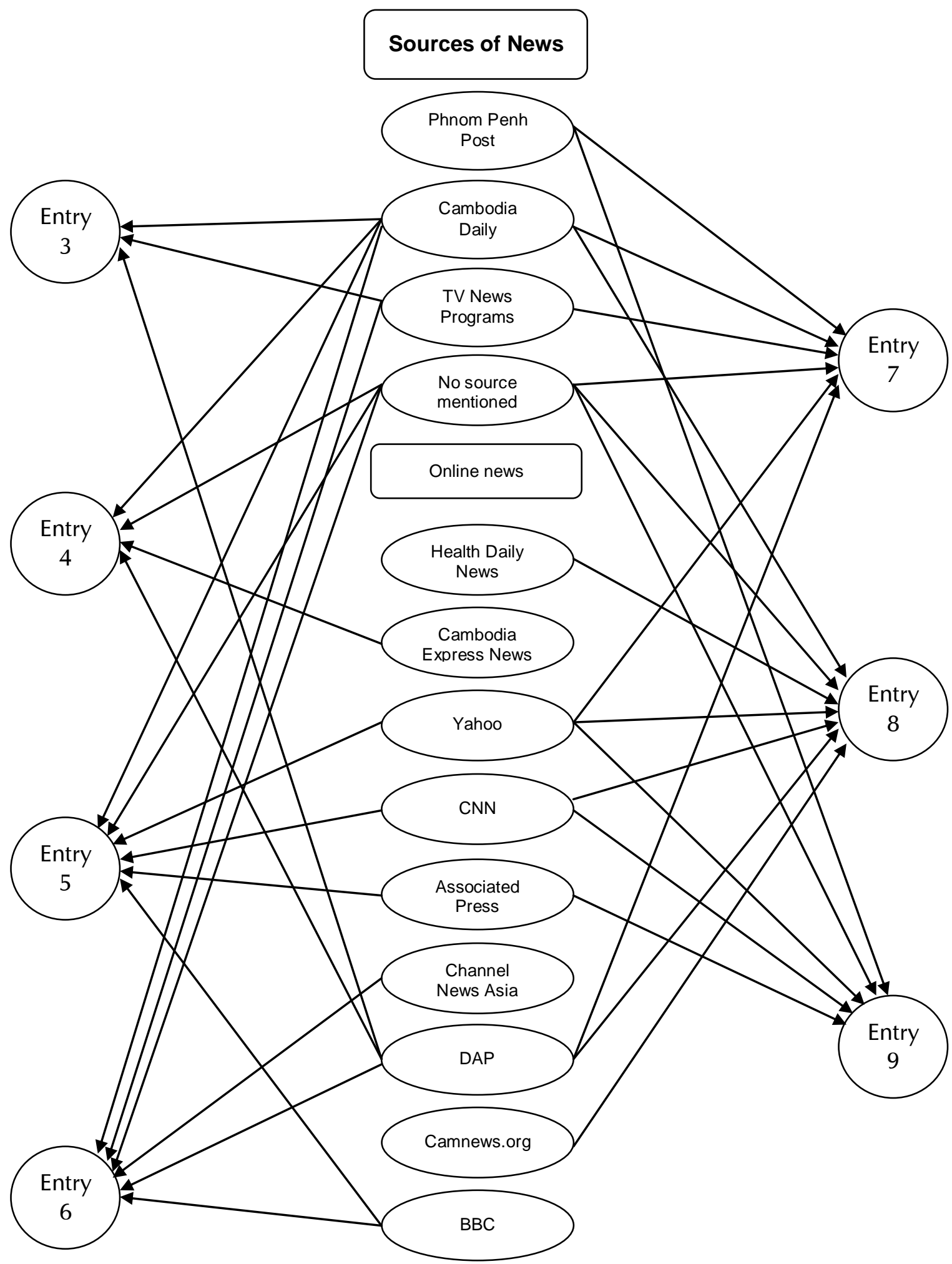

Figure 1. Sources of information from Journal Entries 3 to 9. 
According to Figure 1, Entries 3 and 4 draw on news from only three to four sources, including The Cambodia Daily and DAP; but from Entries 5 to 9 the students started reading news from five to seven sources, including Yahoo, CNN, the Associated Press, Channel News Asia, and the BBC.

Students' increasing knowledge of society is also reflected in the choices of issues they discussed in their journal entries. Most of the issues are controversial and real-life happenings around them, including land disputes, traffic accidents, Cambodians migrating to work in the neighboring countries, the Khmer Rouge Tribunal, and domestic violence. The following two entries illustrate how students discuss some of these issues (for the purpose of this illustration, an example from Journal Entry 10 is also used):

\begin{abstract}
Abroad Maids
Prime Minister Hun Sen personally ordered an immediate ban on sending Cambodian maids to Malaysia. But only two days after, the ministry of labor offered job recruitment agencies as exemption allowing them to continue to send thousands of registered recruit abroad. A secretary of ACRA, Association of Cambodian Recruitment Agencies said he allows who are under training and registered. New recruitment is not allowed any more. He added that, this allowed his company to recover the costs it had incurred for training, transport and travel documents or recruits which were at least $\$ 500, \$ 600$ per recruit. However, if this company keep on doing this, it seem like they act against the Prime Minister's order. A suspension is a suspension. It should not have an exemption to allow the sending of maids to continue. The total of trainees is about id $[\mathrm{sic}]$ about 7,000 which is a large number. So continuing sending is continuing those trainees to become new generation victims since there are a lot of examples in the past of this problem.
\end{abstract}

(F5 Journal Entry 9)

\title{
Overdue Trials?
}

In another one of Cambodia Daily issue today, one article was about the Khmer Rouge leader, brother "number two", Nuon Chea, who's being trialed alongside his other colleagues. In the article he talks about his side of the story of the Khmer Rouge. In short, he protested that their plan was the liberate the country from foreign influence and that the massacre was not their intention but ploys of their enemies, (The Lon Nol government, the Americans and the Vietnamese). In my opinions, these trials have long since passed their due date two decades ago. The ringleaders of the regime, including Mr Nuon Chea, had already lived their lives and are now old men just waiting for their deathbed. In just a few years, all of them would probably just died of old age. Then all these late overdue trials are just pointless in the end. Justice should've been dealt upon them as soon as they were caught. They should have all been given capital punishments for their crimes again humanity and their own countrymen. These people are responsible for approximately two millions deaths during their regime which they started and ran. Hatred for them burns for every living Cambodian who experienced their death-era. Yet when everybody were killed and starved in those four years, these men get to live out their lives for over thirty years and a decisive judgment for them hasn't even been given yet.

(M3 Journal Entry 10) 
Data showing the increasing sources of information students referred to and the choices of issues they discussed in their journal entries suggest that they were expanding their knowledge and awareness of their surrounding environment. Moreover, this was not actually limited to what was happening in Cambodia; some entries discussed more international issues such as the Association of Southeast Asian Nations (ASEAN), globalization, natural disasters, and social networking.

\section{Research Question 2}

An analysis was conducted of students' journal entries to observe their level of elaboration in their responses to the news summary. Each journal entry was coded at one of three levels. Level A contained only a summary of the news students read with no response to it. Level B consisted of a summary and a response, but the response was limited to one sentence only. Level $\mathrm{C}$ also had a summary and a response, which was more elaborate and at a paragraph length or longer. An example of each level follows, with the response part (in Levels B and C) in italics:

Level A

\section{iPhone Battery Issues}

Based on CNN news website updated on 10pm, Apple has fixed iOS5 on the battery performance by releasing iOS5.0.1 after admitted that iOS5 had battery issues. Few weeks ago Apple has released iphone $4 \mathrm{~S}$ and got many complaints about the fast draining out of battery performance. In the mean time, iOS5 which has useful and new improvements on iphone, ipad and ipod, was also released, iOS5 users face with those issues as well. Noticeable what special in iOS5 is iCloud. After checking the performance of iOS5, iOS5.0.1 is released to fix the bug that keep iphone, ipad and ipod processing. However, now Apple is trying to figure out the problem if it still exists.

(F15 Journal Entry 8)

Level B

\section{The Oil Price}

On March 21, 2012, the BBC news report stated that the oil price of the world is now increasing to a very high level. In that morning the oil price trading for Brent crude was up to $\$ 124.43$ per barrel and New York light was $\$ 106.57$ per barrel. It continued that this matter was caused by the trouble in the Middle East and North America and the Iran sanction recently. It was a very big concern for all the country in the world that it will cause all the expenses and the cost of the products will highly increase that may lead too economics obstacle to the world. This main threat has made the oil minister of Saudi Arabia, Ali al-Naimi, said that the country will boost their output to about 3 million barrel more if needed. Hence, even though it is a choice that makes us feel a bit relief, we should still worry about it and try to find some other ways that may better lift up the world economics out of this trouble.

(F10 Journal Entry 6) 
Level C

\section{Rice Wine Poisoning Hits People to Death and Serious Injuries}

Recently I have heard lots about rice wine poisoning in few provinces in Cambodia such as Kampong Thom, Pursat and Kratie. Minority of the victims died while the majority of them are being hospitalized. This news clearly indicates all kinds of alcohol especially the poor quality ones are bad for our health. If you are consuming alcohol, means you are taking high risk already. Wasting money, affecting health, causing death, and losing family and personal honor are the disadvantages alcohols leave for abusers. Thus, to promote harmony life and peaceful society, Cambodia should do away with all kinds of alcohols as well as those addictive drugs. Government should strictly enforce the law about sale and consumptions. Regular checking the quality of alcohol and the due date and limiting the legal age for buying alcohol help bring the government policies to efficiency and effectiveness about this issue. Furthermore, to make sure that everyone all over the country is aware of this, media is the best way to bring this news_laws and disadvantages of alcohol to them in a convenient and fast way.

(F8 Journal Entry 5)

Changes in the level of elaboration in students' responses to the news they read were reflected in their seven entries as shown in Table 1:

Table 1

Elaboration Level of Responses From Entries 3 to 9

\begin{tabular}{|c|c|c|c|}
\hline Entry & $\begin{array}{c}\text { A: No elaboration } \\
\text { (News summary only) }\end{array}$ & $\begin{array}{c}\text { B: } \\
\text { Sentence elaboration }\end{array}$ & $\begin{array}{c}\text { C: } \\
\text { Paragraph elaboration }\end{array}$ \\
\hline 3 & 0 & 3 & 2 \\
\hline 4 & 0 & 1 & 6 \\
\hline 5 & 0 & 1 & 9 \\
\hline 6 & 0 & 2 & 8 \\
\hline 7 & 0 & 0 & 8 \\
\hline 8 & 1 & 0 & 7 \\
\hline 9 & 0 & 0 & 9 \\
\hline
\end{tabular}

According to Table 1, the number of responses at Level $\mathrm{C}$ rose significantly from Journal Entries 3 to 5 and remained high through Entry 9. Because the summary-response genre was not required and only recommended for students in writing their journal entries, not all of them used the genre, but when they did, they tended to be more elaborate in their responses. What is satisfying is not only the increase in their responses and elaboration, but also the quality of their responses, as seen in the following extract: 


\section{The Approval of Sending Maids to Malaysia}

3000 women are planning to departure to work as maids in Malaysia, although there was a speech about the banning made by Prime Minister Hun Sen, for there is the high risk of being abused and exploitation on workers in this country, according to Cambodia Daily volume 50 issue 4. Labor Minister, Mr. Vong Sauth, who has approved this loophole of sending workers to Malaysia, defended his position by saying that what Prime Minister said about the banning applied only to new recruitment activities but not for the one that have already signed the contact with the agency. However, I will not satisfy with these reasons that the banning is valid only to the new recruitment, for the prohibition of this is created because the government considers about the high risk of workers being badly treated in Malaysia, so why those 3000 women are still sent to Malaysia when we know they might face abusing from their employers? Moreover, in my understanding about Prime Minister Hun Sen speech, he did not say this focusing only to new or old recruitment but to the whole. His commend is to suspend all activities involving in the sending of workers to Malaysia, so the sending should not carry on. Additionally, the job as a maid itself is very vulnerable which workers are easy targets for abusing and exploitation since no one they can turn on when they have problem. They work in a house where owner can easily cut their communication from the outsider and abuse them. Overall, I do not accept the idea of sending women to Malaysia to work as maids, but it will be better if the agencies are able to alter the work from being a maid to the work in the factories.

(M2 Journal Entry 5)

Student M2 wrote about the issue of sending Cambodian women to work in Malaysia as housemaids in his Journal Entry 5. Although there are some minor errors in writing, he has shown good understanding of the important conventions in a summary-response genre, which are underlined above. These include the use of reference words or phrases, the use of past tense of the reporting verbs in the summary, stating one's position on the issue, and supporting it with reasons. This is typical of an elaboration at Level C.

\section{Limitations of the Study}

In this action research, the utilization of a local newspaper, the training of students in summaryresponse genre, and the use of journal writing for students to express their voices were designed to address the problem of the students' lack of reading and critical thinking. The results seem to have shown the effectiveness of these interventions; however, any attempt to make generalizations beyond the scope of this study will require an experimental design in which a control group is used. Therefore, caution is needed in the examination of the causal relation between the treatment here and students' knowledge of society and critical thinking. Moreover, a large number of entries were coded as non-summary-response genre and were excluded from the analysis. These writings are in essay format and could be rich in students' opinions in social issues, but inclusion of these entries in the analysis might have slightly skewed the results.

\section{Discussions and Implications}

From the results of this study, it is important to recognize the value of a news-summaryresponse genre especially in a composition class. Not only can it enable students to be aware of the important conventions of the genre, but it also has the potential for promoting social justice. First, students get to read about something that is happening around them in real life. For instance, in this study, they read about and reacted to important social issues in Cambodia, 
such as land disputes, traffic accidents, migration of Cambodian workers to their neighboring countries, the Khmer Rouge Tribunal, and domestic violence. These are controversial and ongoing issues in current Cambodian society. In addition to reading, the students also have a chance to react to the issues through writing. Some of the reactions in this study include identification of potential exploitations of the poor, critiques on the government's policies and measures, and solutions to social problems. As they read and react to news around them, the students become more analytical and critical of their surroundings. This skill is very important for any active citizen in a democratic society.

This study also illustrates that using a journal in the composition class provides students with opportunities to practice writing and also a space for them to express themselves in an anxietyfree environment. Students may be more motivated because they choose to write on their own topic without worrying about making errors, especially in their foreign language. Another reason for this motivation is the connection of their reactions to real-life problems in the news they read; this is also empowering since this journal closely represents the opinion page of a newspaper, where issues discussed are directly of writers' concerns.

Although this study examined the impacts of the use of journal writing, it did not include the instructor's responses as data because they were random and limited. Therefore, future research may include the examination of the roles of these responses on students' motivation and their actual writing.

\section{Author Note}

Virak Chan, English Department, Royal University of Phnom Penh, Phnom Penh, Cambodia

Correspondence concerning this article should be addressed to Virak Chan, English Department, Royal University of Phnom Penh, Russian Federation Boulevard, Toul Kork, Phnom Penh 12010, Cambodia. E-mail: virakifl@fulbrightmail.org 


\section{References}

Elbow, P. (2007). Voice in writing again: Embracing contraries. College Eng/ish, 70(2), 168-188.

Ferris, D. (2003). Responding to writing. In B. Kroll (Ed.), Exploring the dynamics of second language writing (pp. 119-140). Cambridge, England: Cambridge University Press. http://dx.doi.org/10.1017/CBO9781139524810.010

Fitzgerald, J., \& Shanahan, T. (2000). Reading and writing relations and their development. Educational Psychologist, 35(1), 39-50. http://dx.doi.org/10.1207/S15326985EP3501_5

Fazio, L. L. (2001). The effect of corrections and commentaries on the journal writing accuracy of minority- and majority-language students. Journal of Second Language Writing, 10(4), 235-249. http://dx.doi.org/10.1016/S1060-3743(01)00042-X

Grabe, W. (2003). Reading and writing relations: Second language perspectives on research and practice. In B. Kroll (Ed.), Exploring the dynamics of second language writing (pp. 242-262). Cambridge, England: Cambridge University Press. http://dx.doi.org/10.1017/CBO9781139524810.016

Harris, M. (2008). Scaffolding reflective journal writing - Negotiating power, play and position. Nurse Education Today, 28, 314-326. http://dx.doi.org/10.1016/j.nedt.2007.06.006

Holmes, V. L., \& Moulton, M. R. (1997). Dialogue journals as an ESL learning strategy. Journal of Adolescent \& Adult Literacy, 4O(8), 616-621. http://www.jstor.org/stable/40013472

Hyland, K. (2008). Plenary Speeches: Genre and academic writing in the disciplines. Language Teaching, 41(4), 543-562. http://dx.doi.org/10.1017/S0261444808005235

Johns, A. M. (2003). Genre and ESL/EFL composition instruction. In B. Kroll (Ed.), Exploring the dynamics of second language writing (pp. 195-217). Cambridge, England: Cambridge University Press. http://dx.doi.org/10.1017/CBO9781139524810.014

Kim, J. (2005). A community within the classroom: Dialogue journal writing of adult ESL learners. Adult Basic Education, 15(1), 21-32.

Koshy, V. (2005). Action research for improving educational practice. London, England: Sage.

Lovejoy, K. B. (2009). Self-directed writing: Giving voice to student writers. English Journal, 98(6), 79-86. http://www.jstor.org/stable/40503464

Luce-Kapler, R., Catlin, S., Sumara, D., \& Kocher, P. (2011). Voicing consciousness: The mind in writing. Changing English, 18(2), 161-172. http://dx.doi.org/10.1080/1358684X.2011.575249

Meyers, A. (2005). Gateways to academic writing. White Plains, NY: Pearson Education.

Myskow, G., \& Gordon, K. (2010). A focus on purpose: Using a genre approach in an EFL writing class. ELT Journal, 64(3), 283-292. http://dx.doi.org/10.1093/elt/ccp057

Nunan, D. (1992). Research methods in language learning. New York, NY: Cambridge University Press.

Tabatabaei, O., \& Ali, H. A. (2012). The effect of reading-based pre-writing activities on writing performance in an EFL setting. Journal of Educational and Social Research, 2(2), 371 382. Available at http://www.mcser.org/images/stories/JESRJOURNAL/Jesr_May_2012/hamed_amin_ali.pd $f$

Yasuda, S. (2011). Genre-based tasks in foreign language writing: Developing writers' genre awareness, linguistic knowledge, and writing competence. Journal of Second Language Writing, 2O(2), 111-133. http://dx.doi.org/10.1016/j.jslw.2011.03.001 